\title{
The Quantitatively and Qualitatively Potential of the Wine Grape Harvest in Relation with the Wine Climate Milessima
}

\author{
Liliana PIRCALABU ${ }^{1 *}$, Aurelia TUDORACHE ${ }^{1)}$, Adrian SERDINESCU ${ }^{1)}$ and Anca DRAGUNESCU ${ }^{2)}$ \\ ${ }^{1}$ Research Institute for Viticulture and Enology Valea Calugareasca, Romania; street Valea Mantei, No. \\ 1, Valea Calugareasca, Zip code: 107620; \\ ${ }^{2}$ Banat University of Agricultural Sciences and Veterinary Medicine, Timisoara, Calea Aradului, No. 119, \\ zip code: 300645 . \\ ${ }^{*}$ Corresponding author, e-mail: lilianapircalabu@yahoo.com
}

Bulletin UASVM Horticulture 72(1) / 2015

Print ISSN 1843-5254, Electronic ISSN 1843-5394

Doi:10.15835/buasvmcn-hort:10744

\begin{abstract}
Weather and climate play a major role in the quality and quantity of grapes and wine produced; baseline climate has been noted to significantly influence wine style, and climate variability to influence wine yields and quality differences. The greatest potential of any wine grape variety is realized only when it is harvested at the right time in order for the wines to possess the balance intended for its use. The rate of decrease in yield potential was 4.5 from 'Feteasca regala', 20.5 from 'Riesling italian', 24 from 'Cabernet Sauvignon' and 19 from 'Merlot'. The growth rate of glucoacidimetric index was 4.5 from 'Feteasca regala', 2.0 at 'Riesling italian', 14.5 at 'Cabernet Sauvignon' and 5.0 at 'Merlot'. The mathematical models for forecasting the harvest are as follows: $\Delta \mathrm{T}=-0.220 \Delta$ Ind -0.1317 at 'Feteasca regala', $\Delta \mathrm{T}=-0.168 \Delta$ Ind -0.0172 in case of 'Riesling italian', $\Delta \mathrm{T}=-0.173 \Delta$ Ind -0.2758 at 'Merlot' and $\Delta \mathrm{T}=-0.166 \Delta$ Ind -0.6745 at 'Cabernet Sauvignon'.
\end{abstract}

Keywords: climate, quantitative potential, qualitative potential, yield potential.

\section{INTRODUCTION}

During the past few years, the impacts of climate on grape quantity and wine quality have been the subject of extensive studies undertaken in many different parts of the world. The influence of climatic variability and of recent trends in the climate in different parts of Europe has been examined by Cazacu (1999), Pîrcălabu (2010), Santos et al., (2011).

The style of wine produced in a region is a result of the baseline climate, while the climatic variability determines differences in the quality of the vintage (Daux et al., 2007; Jones, 2005; Battaglini et al., 2008; Antonio, 2013; Coombe, 1987). The production and quality of wines is likely to be affected by changes in meteorological and climatic conditions.

The date of previous harvests can be used as a guide when trying to determine the projected harvest date (Goldammer, 2013). The potential of grapes harvest is a result of the interaction of natural factors, biological and agronomical and has a specificity of the terroir and millesima (harvest year). Its level represents the criterion for determining the destination for the wine grape production capitalization. Winemakers have been using the ratio between sugars and acids as an indication of the ripeness degree for determining when the grapes are ready to be harvested (Hunter et al. 2004).

\section{MATERIALS AND METHODS}

The work was performed to quantify the parameters for harvest potential, specific to the main varieties of Valea Calugareasca vineyard and milessima (average, good and very good). The information concerning wine-growing climate and 
harvest potential was used for defining the model of forecasting of the grapes harvest date.

The study was conducted during 20002013 years for 'Feteasca regala', 'Riesling italian', 'Cabernet Sauvignon' and 'Merlot' varieties. Viticultural climate parameters analyzed were: air temperature, precipitation and insolation. The evaluation was done through comparative analysis of the annual values with multiannual values. The temperature, rainfall and insolation were evaluating using scores. Based on the amplitude of the variation were established for each parameters a number of five levels: low, mediocre, good, very good and exceptionally, and were defined the interval of hierarchy related to the miximum and the minimum limit.

Potential quantitatively evaluated on the basis of potential yield and qualitative potential has been defined by the weight and volume of grain, sugar, acidity, gluco-acidimetric index and content of anthocyanins from black grape varieties. The prediction of date harvest is founded by the relationship $\Delta \mathrm{T}=-\mathrm{x}^{*} \Delta \mathrm{Ind}$, where $\Delta \mathrm{T}$ is the difference between the annual and multiannual average maximum temperature during the period April-August and $\Delta$ Ind is the difference between the multiannual and annual veraison date.

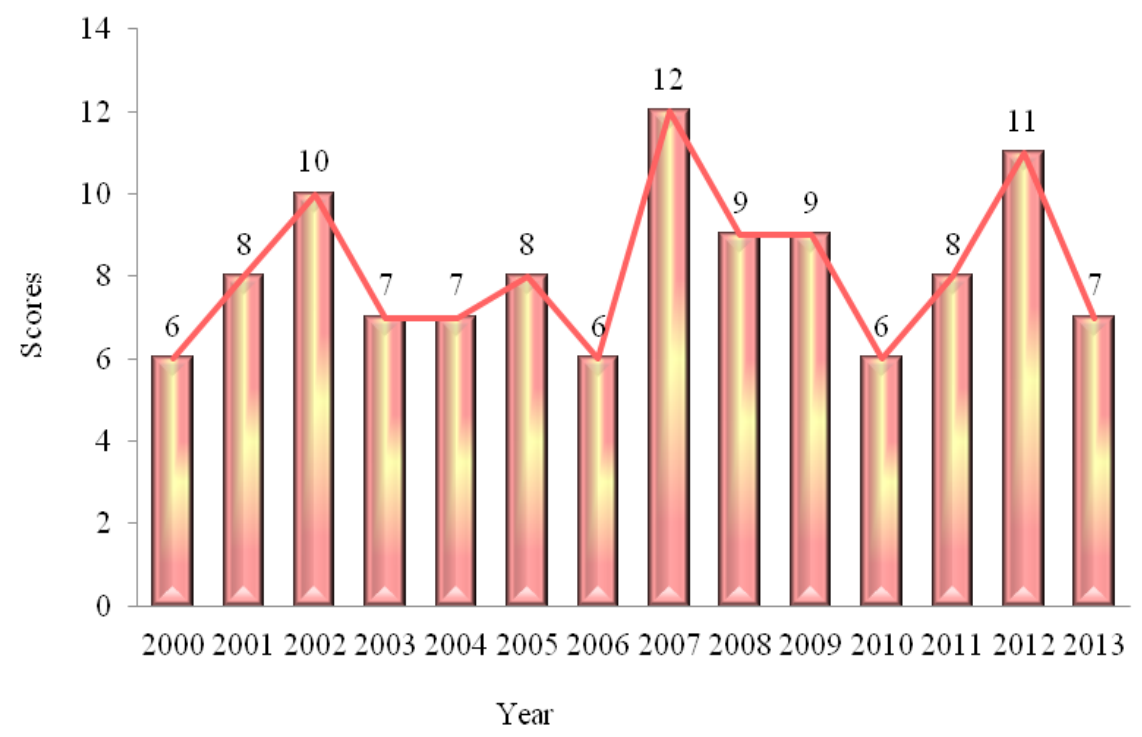

Fig. 1. The viticultural climate of the DOC Dealu Mare-Valea Calugareasca area, evaluated on the basis of temperature, precipitation and insolation, for the period 2000-2013.

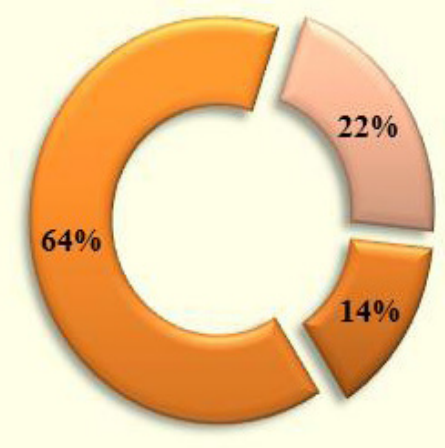

Medium $\square$ Good $\square$ Very good

Fig. 2. The frequency of viticultural milessima in the DOC Dealu Mare Valea Calugareasca area, during the period 2000-2013.
Tab. 1. Production of grape $(\mathrm{kg} / \mathrm{vine})$ in relation to the variety and viticultural milessima in DOC Dealu Mare-Valea Calugareasca area.

\begin{tabular}{ccccc}
\hline $\begin{array}{c}\text { Milessima/ } \\
\text { Variety }\end{array}$ & $\begin{array}{c}\text { 'Feteasca } \\
\text { regala' }\end{array}$ & $\begin{array}{c}\text { 'Riesling } \\
\text { italian' }\end{array}$ & $\begin{array}{c}\text { 'Cabernet } \\
\text { Sauvignon' }\end{array}$ & 'Merlot' \\
\hline Medium & 3,700 & 3,555 & 4,090 & 3,825 \\
\hline Good & 3,545 & 2,715 & 3,267 & 3,380 \\
\hline Very good & 3,430 & 2,320 & 2,500 & 2,575 \\
\hline
\end{tabular}




\section{RESULTS AND DISCUSSION}

1. The climate wine quality during the period 2000-2013

During the analyzed period, in the DOC Dealu Mare-Valea Calugareasca area, evaluating the climate parameters allowed the identification of the following types of climates (Fig. 1):

- type 1 - low: years 2000, 2006 and 2010

- type 2 - mediocre: years 2003, 2004 and 2013

- type 3 - good: years 2001, 2005 and 2011

- type 4 - very good: years 2008 and 2009

- type 5 - exceptional: years 2002, 2007 and 2012

The frequency of mediocre climate was $14 \%$, of the good climate $64 \%$ and a very good climate of $21 \%$ (Fig. 2).

2. The quantitative potential of the grape harvest in terms of wine climate milessima

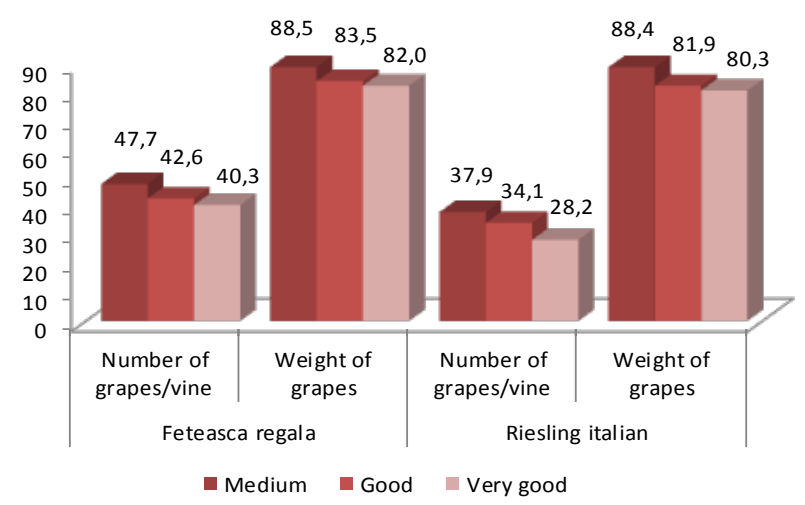

Fig. 3. The quantitative potential of the grape harvest of 'Feteasca regala' and 'Riesling italian'varieties, in the studied area.

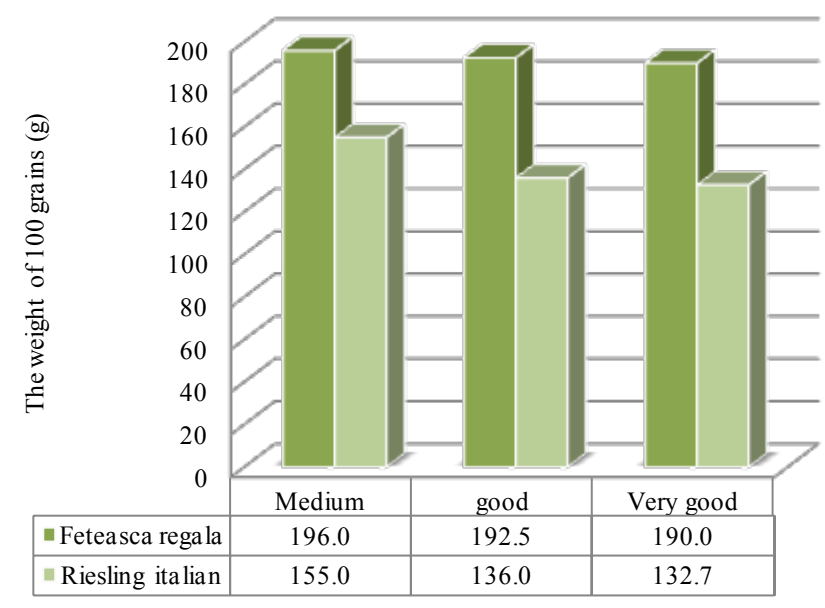

Fig. 5. Weight of 100 berries of varieties for white wines depending on the potential quality of the harvest, in the studied area.
The production of grape varieties taken into study was specific to milessima.

'Feteasca regala' variety recorded a reduction in the production of grapes from the mediocre to very good level an average with $0.16 \mathrm{~kg} /$ vine, 'Riesling italian' variety with $0.52 \mathrm{~kg} / \mathrm{vine}$, 'Cabernet Sauvignon' with $0.79 \mathrm{~kg} / \mathrm{vine}$, and 'Merlot' with $0.62 \mathrm{~kg} / \mathrm{vine}$ (Tab. 1).

The grape production is dependent on the average weight of the grape and the number of grapes per vine. The average number of grapes/ vine of 'Feteasca regala' variety recorded variations from medium level 47.7 to very good level 40.3, and the average weight of a grape from $88.5 \mathrm{~g}$ (medium level) at $83.0 \mathrm{~g}$ (very good level). Italian Riesling variety recorded the same variations from the average level (37.9) to very good level (28.2),

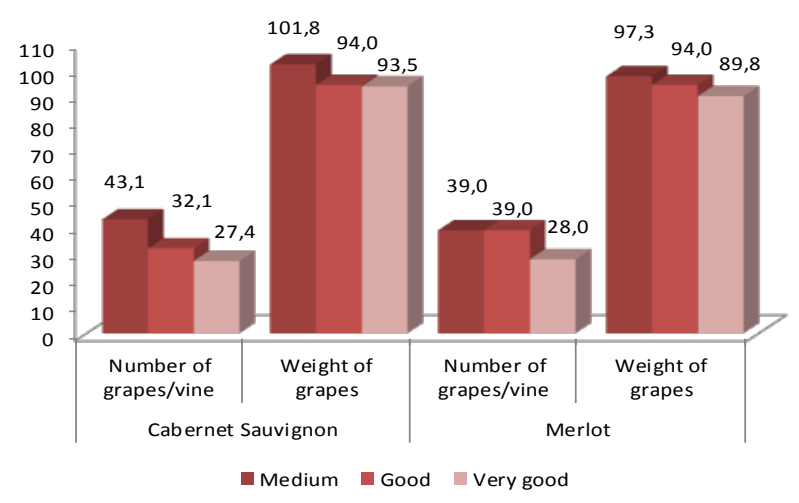

Fig. 4. The quantitative potential of the grape harvest of 'Cabernet Sauvignon' and 'Merlot' verieties, in the studied area.

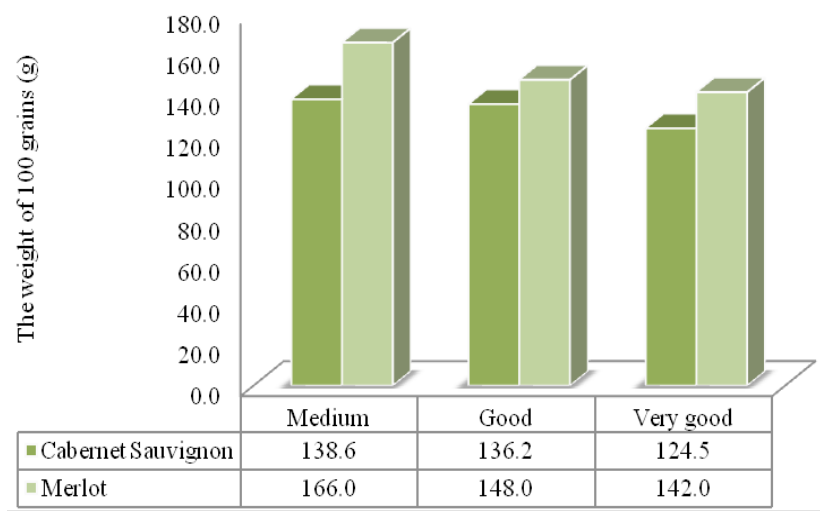

Fig. 6. Weight of 100 berries of varieties for red wines depending on the potential quality of the harvest, in the studied area. 
while the average weight of a grape from $88.4 \mathrm{~g}$ (medium level) to $80.3 \mathrm{~g}$ (very good level) (Fig. 3).

In the case of varieties for red wine, the numbers of grapes on the vine number varies from 43.1 (medium level) at 27.4 (very good level) in the case of the 'Cabernet Sauvignon' variety and between 39 (medium level) and 28 (very good level) in the case of the 'Merlot' variety. In terms of the average weight of a grape were recorded values between $101.8 \mathrm{~g}$ (medium level) and $93.5 \mathrm{~g}$ (very good level) to 'Cabernet Sauvignon', respectively $97.3 \mathrm{~g}$ (medium level) at $89.8 \mathrm{~g}$ (very good level) to 'Merlot' variety (Fig. 4).

The yield in the wine variety for white wines, characterized by the weight of 100 grains, was reduced from $196 \mathrm{~g}$ (medium level) to $190 \mathrm{~g}$ (very good level) in the case of the 'Feteasca regala' variety, from $155 \mathrm{~g}$ an medium level at $132.7 \mathrm{~g}$ very good level in the case of 'Riesling italian'variety (Fig. 5).

In the case of varieties for red wines the weight of 100 grains presented values of $138.6 \mathrm{~g}$ (medium level) at $124.5 \mathrm{~g}$ (very good level) in the case of the variety 'Cabernet Sauvignon', and 'Merlot' variety the weight decreased from the medium level (166 g) at very good level (142 g) (Fig. 6).

In Valea Calugareasca viticultural areal the glucoacidimetric index at the varieties of grapes for the red wines, in case of 'Cabernet Sauvignon' variety oscilated between 21 (medium level) and 49 (very good level), and at 'Merlot' variety between 37 (medium level) to 47 (very good level), (Tab. 2).

In the case of varieties for white wine has registered the lowest potential impact on quality of wine harvest milesima, with values of glucoacidimetric index between 35 (medium level) and 44 (very good level) for 'Feteasca regala' variety and between 45 (medium level) and 49 (very good level) for the 'Riesling italian'variety, the values are specific to each variety.

The alcoholic potential for white wine variety, has registered variations between $10.9 \%$ vol alcohol (medium level) to $11.3 \%$ vol. alcohol (very good level) at 'Feteasca regala' variety, and from $10.8 \%$ vol. alcohol (medium level) to $11.1 \%$ vol. alcohol (very good) level at 'Riesling italian'variety (Tab. 3).

In the varieties of grapes for the red wines varies in case of 'Cabernet Sauvignon' variety between 10.7\% vol alcohol (medium level) and
$12.5 \%$ vol. alcohol (very good level), and the 'Merlot' variety between $11.5 \%$ vol. alcohol (medium level) to $12.6 \%$ vol. alcohol (very good level).

\section{Predicting the date of harvest}

The prediction of date harvest is founded by the relationship $\Delta \mathrm{T}=-\mathrm{x}^{*} \Delta \mathrm{Ind}$, where $\Delta \mathrm{T}$ is the difference between the annual and multiannual average maximum temperature during the period April-August and $\Delta$ Ind the difference between the multiannual and annual veraison date. Equations modeling show tight correlations for all the varieties examined in the Dealu Mare-Valea Calugareasca area, showing regression coefficient with values between 0.92 in case the 'Merlot' variety, 0.94 in the case of 'Cabernet Sauvignon' variety and 0.95 for 'Riesling italian' and 'Feteasca regala' varieties. The relation coefficients are specific to variety (Tab. 4).

Tab. 2. The influence of viticultural milessima and variety on the quality of the production, in DOC Dealu Mare-Valea Calugareasca area.

\begin{tabular}{|c|c|c|c|c|}
\hline $\begin{array}{c}\text { Milessima/ } \\
\text { Variety }\end{array}$ & $\begin{array}{c}\text { 'Feteasca } \\
\text { regala' }\end{array}$ & $\begin{array}{l}\text { 'Riesling } \\
\text { italian' }\end{array}$ & $\begin{array}{l}\text { 'Cabernet } \\
\text { Sauvignon' }\end{array}$ & 'Merlot' \\
\hline \multicolumn{5}{|c|}{ Sugar $(\mathrm{g} / \mathrm{l})$} \\
\hline Medium & 191,5 & 187,4 & 185,3 & 198,0 \\
\hline Good & 192,3 & 188,4 & 198,4 & 203,3 \\
\hline Very good & 194,7 & 191,2 & 215,1 & 216,9 \\
\hline \multicolumn{5}{|c|}{ Acidity $\left(\mathrm{g} / \mathrm{l} \mathrm{H}_{2} \mathrm{SO}_{4}\right)$} \\
\hline Medium & 5,5 & 4,2 & 8,7 & 5,3 \\
\hline Good & 5,4 & 4,0 & 6,3 & 5,1 \\
\hline Very good & 4,6 & 4,0 & 4,4 & 4,7 \\
\hline \multicolumn{5}{|c|}{ c) Glucoacidimetric index } \\
\hline Medium & 35 & 45 & 21 & 37 \\
\hline Good & 37 & 48 & 34 & 40 \\
\hline Very good & 44 & 49 & 49 & 47 \\
\hline
\end{tabular}

Tab. 3. The influence of viticultural milessima and variety on the alcoholic potential of wines, in DOC Dealu Mare-Valea Calugareasca area.

\begin{tabular}{ccccc}
\hline $\begin{array}{c}\text { Milessima/ } \\
\text { Variety }\end{array}$ & $\begin{array}{c}\text { 'Feteasca } \\
\text { regala' }\end{array}$ & $\begin{array}{c}\text { 'Riesling } \\
\text { italian' }\end{array}$ & $\begin{array}{c}\text { 'Cabernet } \\
\text { Sauvignon' }\end{array}$ & 'Merlot' \\
\hline Medium & 10.9 & 10.8 & 10.7 & 11.5 \\
\hline Good & 11.1 & 10.9 & 11.5 & 11.6 \\
\hline Very good & 11.3 & 11.1 & 12.5 & 12.6 \\
\hline
\end{tabular}


Tab. 4. The modeling relationship between $\Delta \mathrm{T}$ and $\Delta$ ind depending on the studied variety, in DOC Dealu Mare-Valea Calugareasca area.

\begin{tabular}{ccc}
\hline Variety & The regression equation & The regression coefficient \\
\hline 'Cabernet Sauvignon' & $\Delta \mathrm{T}=-0.166 \Delta$ Ind -0.6745 & 0.94 \\
\hline 'Merlot' & $\Delta \mathrm{T}=-0.173 \Delta$ Ind -0.2758 & 0.92 \\
\hline 'Riesling italian' & $\Delta \mathrm{T}=-0.168 \Delta$ Ind $+0,0172$ & 0.95 \\
\hline 'Feteasca regala' & $\Delta \mathrm{T}=-0.220 \Delta$ Ind $-0,1317$ & 0.95 \\
\hline
\end{tabular}

Note: $\Delta \mathrm{T}$ (the difference between the annual and multiannual average maximum temperature during the period April-August) and $\Delta \operatorname{Ind}$ ( the difference between the multiannual and annual veraison date).

\section{CONCLUSION}

The wine growing area are strongly influenced by climate. In the present paper, we have investigated the relationships between climatic variability and the quantitatively and qualitatively potential of the grape production and wine quality in the DOC Dealu Mare Valea Calugareasca. Our main conclusions are as follows: 1 . year to year variations in climate also influence the potential of the wine harvest which is poor at 'Feteasca regala' and very high at 'Cabernet Sauvignon'. 2. regarding the yield potential of the grape production was found that the rate of decrease was 4.5 from 'Feteasca regala', 20.5 from 'Riesling italian', 24 from 'Cabernet Sauvignon' and 19 from 'Merlot', and the growth rate of glucoacidimetric index was 4.5 from 'Feteasca regala', 2.0 at 'Riesling italian', 14.5 at 'Cabernet Sauvignon' and 5.0 at 'Merlot'. In the studied period, in the area Dealu Mare-Valea Calugareasca, the wine of medium quality had a share of $14 \%$, the best $64 \%$ and very good $21 \%$. The two results are useful tools of vine grower and winemaker to exploit the optimal grape harvest and to maximize the economic efficiency of the grapes production.

\section{REFERENCES}

1. Antonio T, Jose ED, Simone DC and Hernani G (2013). Berry Phenolics of Grapevine under Challenging Environments, Int. J. Mol. Sci., 14, 18711-18739; doi: 10.3390/ijms 140918711, ISSN 1422-0067.

2. Battaglini A, Barbeau G, Bindi M, Badeck FW (2008). European winegrowers' perceptions of climate change impact and options for adaptation. Regional Environmental Change. doi 10.1007/s10113-008-0053-9.

3. Cazacu S (1999). Model based on physiological processes for simulation of harvest grape formation at Merlot variety, depending on local climate in Valea Calugareasca vineyard, PhD Thesis, ASAS Bucuresti.

4. Coombe BG (1987). Influence of temperature on composition and quality of grapes. Acta Hort., 206, 23-36.

5. Daux V, Yiou P, Le Roy Ladurie E, Mestre O, Chevet JM (2007). Temperature et dates de vendanges en France. Symposium Rechauffement climatique, quels impacts probables sur les vignobles?

6. Goldammer T, (2013). Grape Grower's Handbook, Apex Publishers, First Edition, Printed in USA.

7. Hunter JJ, Pisciotta A, Volschenk CG,Archer E, Novello V, Kraeva E, Deloire A, Nadal M. (2004). Role of harvestingtime/optimal ripeness in zone/terroir expression. Proc. Joint OIV, GESCO, SASEV Intl Conference on Viticultural Zoning, 15-19 November 2004, Cape Town, South Africa, 466-478.

8. Jones G (2005). Climate change in the western United States grape growing regions. Acta Horticulturae, http:// www.actahort.org/books/689/689_2.htm.

9. Pîrcălabu L (2010). Research on the delimitation of the "terroir" and the management information system whit special regard upon Valea Calugareasca vineyard, $\mathrm{PhD}$ Thesis, ASAS Bucuresti .

10. Santos JA, Malheiro AC, Karremann MK, Pinto JG (2011). Statistical modelling of grapevine yield in the Port Wine region under present and future climate conditions. Int J Biometeorol 55:119-131. 